\title{
Alpha-lipoic acid protects against cadmium-induced hepatotoxicity via calcium signalling and gap junctional intercellular communication in rat hepatocytes
}

\author{
Hui Zou*, Xuezhong Liu*, Tao Han, Di Hu, Yan Yuan, Jianhong Gu, Jianchun Bian \\ and Zongping Liu \\ College of Veterinary Medicine, Yangzhou University, and Jiangsu Co-innovation Center for Prevention and Control \\ of Important Animal Infectious Diseases and Zoonoses, Yangzhou, Jiangsu 225009, China
}

(Received January 25, 2015; Accepted April 27, 2015)

\begin{abstract}
This study investigated the protective effect of alpha-lipoic acid (LA) on cadmium (Cd)-induced hepatotoxicity in BRL 3A rat liver cells. We demonstrated that LA ameliorated Cd-induced cellular injury in cell viability and nuclear fragmentation in BRL 3A cells. Furthermore, LA markedly ameliorated Cd-induced gap junctional intercellular communication (GJIC) inhibition and Cx43 mRNA expression decrease, as well as disassembly of gap junctions. The gap junction blocker carbenoxolone disodium (CBX) as well as LA protected healthy cells from Cd-exposed cells in Transwell co-culture system. LA also protected BRL 3A cells against $\mathrm{Cd}$-induced elevation of the intracellular concentration of free calcium $\left(\left[\mathrm{Ca}^{2+}\right]_{\mathrm{i}}\right)$. Pretreatment with a chelater of intracellular $\mathrm{Ca}^{2+}$ BAPTA-AM or chelater of extracellular $\mathrm{Ca}^{2+}$ EGTA attenuated Cd-induced cytotoxicity and GJIC inhibition. CBX exacerbated the decrease in cell viability and further elevated the increase in $\left[\mathrm{Ca}^{2+}\right]_{\mathrm{i}}$ induced by $\mathrm{Cd}$, whereas BAPTA-AM partly attenuated these phenomena, while EGTA had little effects. These results suggested that Cd-induced hepatotoxicity via GJIC inhibition and $\left[\mathrm{Ca}^{2+}\right]_{\mathrm{i}}$ elevation, which originates mainly from intracellular stores. GJIC inhibition has dual effects: (i) it restricts release of $\mathrm{Ca}^{2+}$ from the cell, which exacerbates the $\left[\mathrm{Ca}^{2+}\right]_{\mathrm{i}}$ elevation and cytotoxicity induced by $\mathrm{Cd}$; and (ii) it protects healthy cells from their dangerous neighbors by blocking intercellular communication. Above all, our results indicated that LA partly prevented Cd-induced cytotoxicity via GJIC and calcium signaling in BRL 3A rat liver cells.
\end{abstract}

Key words: Alpha-lipoic acid, Calcium, Cadmium, Connexin, Hepatotoxicity, Calmodulin

\section{INTRODUCTION}

Cadmium (Cd) as a toxic metal is not an essential trace element for animals and humans (Rennolds et al., 2012). The liver is the major target organ for Cd. Damage due to oxidative stress as well as signaling cascades induced by Cd can cause hepatotoxicity (Thévenod, 2009; Järup and Åkesson, 2009). However, the underlying mechanism of Cd-induced hepatotoxicity is not known.

Survival or death of cells is influenced by adjacent cells. Gap junctions provide direct communication between adjacent cells through hydrophilic and small molecules $(<1,000 \mathrm{Da})$ such as cyclic adenosine monophosphate, adenosine triphosphate (ATP), inositol triphosphate (IP3), as well as ions $\left(\mathrm{Ca}^{2+}, \mathrm{Na}^{+}, \mathrm{K}^{+}\right)$, and cellular metabolites (Alexander and Goldberg, 2003). Gap junctional intercellular communication (GJIC) has an important role in several biological processes, including controlling the differentiation and proliferation of cells as well as apoptosis. GJIC is regulated at several levels, including channel gating and connexin expression (Vinken et al., 2011). Cd is known to disrupt the function of gap junctions of hepatocytes in vitro and in vivo (Boucherie et al., 2013; Hu et al., 2002).

$\mathrm{Ca}^{2+}$ is a messenger involved in multiple signaling cascades. Maintenance of $\mathrm{Ca}^{2+}$ homeostasis is essential for cell survival (Clapham, 2007). Studies have shown that $\mathrm{Cd}$ disrupts $\mathrm{Ca}^{2+}$ homeostasis to activate gene transcription and trigger the death or survival of cells (Han et al., 2013; Liu et al., 2014; Zou et al., 2014a). Cd induces dynaminrelated protein 1-dependent mitochondrial fragmentation by triggering elevation of the concentration of intracellu-

Correspondence: Zongping Liu (E-mail: liuzongping@yzu.edu.cn)

*These authors equally contributed to this work. 
lar calcium (i.e., $\left.\left[\mathrm{Ca}^{2+}\right]_{\mathrm{i}}\right)$ to promote hepatotoxicity $(\mathrm{Xu}$ et al., 2013). Elevation of $\left[\mathrm{Ca}^{2+}\right]_{\mathrm{i}}$ can occur owing to: IP3 production; release of sequestered $\mathrm{Ca}^{2+}$ from intracellular stores; activation of $\mathrm{Ca}^{2+}$-dependent phospholipase $\mathrm{C}$; prevention of $\mathrm{Ca}^{2+}$ efflux via inhibition of $\mathrm{Ca}^{2+}$-ATPase (Choong et al., 2014). As the major receptor of $\left[\mathrm{Ca}^{2+}\right]_{\mathrm{i}}$, calmodulin (CaM) has an important role in apoptosis. Overexpression and antagonism of CaM can lead to the induction of apoptosis (Yu et al., 2002; Wu et al., 2005).

Alpha-lipoic acid (LA), found naturally in plants and animals, is a free radical scavenger and potent natural antioxidant. LA is a water- and fat-soluble, sulfur-containing compound proven as a metal chelator (Al-Majed et al., 2002). Previous studies have demonstrated that LA has a protective effect on Cd-induced oxidative stress (Veljkovic et al., 2012; Hussein et al., 2014), however, the underlying mechanism is not clear.

In this study, we investigated the role of the $\mathrm{Ca}^{2+}$ signaling pathway and GJIC in Cd-induced cytotoxicity in BRL 3A cells. Furthermore, we investigated the protective effects of alpha-lipoic acid (LA) as well as the underlying mechanisms.

\section{MATERIALS AND METHODS}

\section{Materials}

3-(4,5-Dimethylthiazol-2-yl)-2,5-diphenyl-tetrazolium bromide (MTT) was purchased from Amresco (Solon, OH, USA). Dulbecco's modified Eagle's medium (DMEM) and fetal bovine serum (FBS) were obtained from Gibco (Life Technologies, Grand Island, NY, USA). PrimeScript RT Reagent kit and SYBR Premix Ex Taq were obtained from TaKaRa Biotechnology (Dalian, China). Oligonucleotide primers were synthesized by Invitrogen (Carlsbad, CA, USA). Other reagents were purchased from Sigma-Aldrich (Saint Louis, MO, USA).

\section{Cell culture}

The BRL 3A rat liver cell line was purchased from the Cell Bank of the Institute of Biochemistry and Cell Biology (Shanghai, China). Cells were resuspended in DMEM supplemented with 10\% FBS, $100 \mathrm{U} / \mathrm{mL}$ penicillin, and $100 \mu \mathrm{g} / \mathrm{mL}$ streptomycin and were cultured at $37^{\circ} \mathrm{C}$ in $95 \%$ humidified air containing $5 \% \mathrm{CO}_{2}$. In all experiments, BRL $3 \mathrm{~A}$ cells were treated with non-serum medium containing $\mathrm{Cd}$ at $90 \%$ confluence, in addition, LA was co-treated with $\mathrm{Cd}$ for $12 \mathrm{hr}$.

\section{Measurement of cell viability}

BRL 3A cells were cultured in flat-bottomed 96-well plates. After treatments, cells were incubated with MTT
$(0.5 \mathrm{mg} / \mathrm{mL})$ for $4 \mathrm{hr}$ at $37^{\circ} \mathrm{C}$. After discarding the medium, $150 \mu \mathrm{L}$ of dimethyl sulfoxide was added to each well, and the plate shaken gently for $10 \mathrm{~min}$ at $37^{\circ} \mathrm{C}$. The optical density (OD) of each well was read at $490 \mathrm{~nm}$ with a Sunrise ${ }^{\mathrm{TM}}$ Microplate Reader (Tecan, Groedig, Austria). Cell viability was expressed as the proportion of OD to that of the control. Each experiment was repeated three times.

\section{Scrape-loading/dye transfer assay for GJIC}

GJIC was measured by the scrape loading/dye-transfer method (SL/DT) as described originally by El-Fouly et al. (1987). In brief, after treatments for $12 \mathrm{hr}$, cells were scraped with a sharp blade dozens of times, and then incubated with Lucifer yellow ( $\mathrm{LY}, 0.5 \mathrm{mg} / \mathrm{mL}$ ) in the dark for $3 \mathrm{~min}$ at $37^{\circ} \mathrm{C}$. Cells were washed three times with PBS and fixed with 4\% paraformaldehyde (SigmaAldrich). GJIC was the mean distance traveled $(\mu \mathrm{m})$ by LY dye from the scraped edge to neighboring cells from nine sites in each sample as measured using a Fluorescent Microscope (DMI 3000B; Leica, Solms, Germany).

\section{Immunofluorescence and laser confocal microscopy}

BRL 3A cells were grown on glass coverslips. After treatments for $12 \mathrm{hr}$, cells were fixed with $4 \%$ paraformaldehyde. Then, cells were rinsed with PBS and permeabilized with Triton X-100 $(0.1 \% v / v)$, followed by incubation with $5 \%$ bovine serum albumin (BSA) in TBS with $0.1 \%$ Tween-20. Cells were incubated with antibody against $\mathrm{Cx} 43$ (1:200 dilution) overnight at $4^{\circ} \mathrm{C}$, then incubated at room temperature for $1 \mathrm{hr}$ with goat anti-rabbit IgG FITC-conjugated antibodies (1:100 dilution). Finally, cells were incubated with 4',6-diamidino-2-phenylindole dihydrochloride (DAPI; 1:100 dilution). Coverslips were mounted onto glass slides and imaged using a Laser Scanning Confocal Microscope (LSM-710; Zeiss, Oberkochen, Germany).

\section{RNA extraction, reverse transcription, and quantitative reverse-transcription-polymerase chain reaction ( $q R T-P C R$ )}

Total cellular RNA was extracted from BRL 3A cells using TRIzol ${ }^{\circledR}$ Reagent (Invitrogen) according to manufacturer instructions. cDNA was reverse-transcribed from total RNA (900 ng) using a PrimeScript RT Reagent kit with gDNA Eraser (Takara Biotechnology). Primers were designed using Primer Premier 5 and were (forward and reverse, respectively): $\beta$-actin, CGTTGACATCCGTAAAGACCTC and TAGGAGCCAGGGCAGTAATCT; Cx43, ACTCTCGCCTATGTCTCCTCC and GTTGGTCCAC- 
Alpha-Lipoic acid and Cd-induced increases in $\left[\mathrm{Ca}^{2+}\right]_{\mathrm{i}}$

GATGGCTAAT; CaM, CACCATTGACTTCCCAGAG and TGTAGCCATTGCCATCCT. Gene expression was measured using a real-time PCR system (7500; Applied Biosystems, Foster City, CA, USA). Reactions were undertaken using a SYBER Premix Taq ${ }^{\mathrm{TM}}$ II kit (TaKaRa Biotechnology) according to manufacturer instructions. Annealing temperatures were $60^{\circ} \mathrm{C}$ for $\beta$-actin and $\mathrm{Cx} 43$, and $57^{\circ} \mathrm{C}$ for CaM. Analyses of relative mRNA expression were carried out using the $\Delta \Delta C_{\mathrm{T}}$ method. Values were normalized using $\beta$-actin as an endogenous housekeeping control gene.

\section{Co-culture of BRL $3 A$ cells}

To investigate the role of GJIC in Cd-induced cytotoxicity, BRL 3A cells were seeded on the inner surface of polyester membrane Transwell Cell Culture Inserts (pore size, $0.4 \mu \mathrm{m}$; surface area, $4.67 \mathrm{~cm}^{2}$; Corning, Corning, NY, USA) in DMEM supplemented with $10 \%$ FBS until confluent. Then inserts were removed from the culture medium and incubated in non-serum DMEM with Cd $(10 \mu \mathrm{M})$ for $12 \mathrm{hr}$. After that, overturning inserts, normal BRL $3 \mathrm{~A}$ cells were seeded on the outside surface of inserts and incubated in condition medium with LA $(50 \mu \mathrm{M})$ or CBX $(50 \mu \mathrm{M})$ for $36 \mathrm{hr}$. After treatments, cells on the inside surfaces of inserts were wiped carefully with a cotton swab. Remaining cells on the outside surfaces of inserts were washed thrice with cold PBS, and then fixed in paraformaldehyde. Fixed cells were stained with Hoechst 33258. Images were obtained using an Inverted Fluorescence Microscope (Leica) at an excitation wavelength of 330-380 $\mathrm{nm}$ using filters of wavelength 450-490 nm.

\section{Measurement of $\left[\mathrm{Ca}^{2+}\right]_{\mathrm{i}}$}

Fluo-4/AM was used as an intracellular fluorescent probe to detect $\left[\mathrm{Ca}^{2+}\right]_{\mathrm{i}}$ in Cd-exposed BRL 3A cells. Briefly, after treatments for $12 \mathrm{hr}$, cells were harvested and incubated with Fluo-4/AM (5 mM) for $30 \mathrm{~min}$ at $37^{\circ} \mathrm{C}$ in the dark. Then, stained cells were washed three times with PBS, and analyzed immediately on a BD-FACS Aria Flow Cytometer (Becton Dickinson, Franklin Lakers, NJ, USA). $\left[\mathrm{Ca}^{2+}\right]_{\mathrm{i}}$ levels were represented by fluorescent intensity. Excitation and emission wavelengths were $494 \mathrm{~nm}$ and $516 \mathrm{~nm}$, respectively. Data were analyzed using Cell Quest (Becton Dickinson).

\section{Statistical analyses}

Each experiment was repeated at least thrice. Data are the mean \pm standard deviation (S.D.). Data comparisons among groups were undertaken using non-parametric, one-way ANOVA followed by the Dunnett's t-test. $p<0.05$ was considered significant and $p<0.01$ as extremely significant.

\section{RESULTS}

\section{Protective effects of LA on Cd-induced changes in the viability and morphology of cells}

To choose the appropriate concentration of Cd and LA for our studies, BRL 3A cells were treated with several concentrations of $\mathrm{Cd}$ and LA for $12 \mathrm{hr}$ to determine the effect of $\mathrm{Cd}$ and LA on cell viability. $\mathrm{Cd}(0-10 \mu \mathrm{M})$ led to a concentration-dependent decrease in cell viability (Fig. 1A and B). Viability of cells treated with $\geq 2.5 \mu \mathrm{M}$ Cd was extremely significantly lower than that of control cells $(p<0.01)$. LA $(25$ and $50 \mu \mathrm{M})$ did not alter cell viability compared with control, whereas LA (100 and $200 \mu \mathrm{M})$ decreased cell viability extremely significantly $(p<0.01)$. These results made us choose $2.5 \mu \mathrm{M} \mathrm{Cd}$ and $50 \mu \mathrm{M}$ LA for subsequent studies. To verify the effect of LA on Cd-induced cytotoxicity, cells were incubated with LA and Cd for $12 \mathrm{hr}$. LA attenuated the reduction in cell viability induced by $\mathrm{Cd}(p<0.05)$ (Fig. $1 \mathrm{C})$. LA had no effect on cell morphology compared with the control, whereas $\mathrm{Cd}$ altered cell morphology: round and shrunken cells were observed, co-incubation with LA could reduce the morphological damage induced by Cd (Fig. 1D).

\section{Protective effects of LA on Cd-induced GJIC inhibition in BRL $3 A$ cells}

Exposure to $\mathrm{Cd}$ inhibited the function of the gap junction of BRL $3 \mathrm{~A}$ cells extremely significantly $(p<0.01)$, and LA blocked Cd-induced GJIC inhibition (Fig. 2A and B). Cx43 distribution in BRL 3A cells was observed using confocal immunofluorescence microscopy (Fig. 2C). In control and LA groups, Cx43-positive gapjunction plaques were predominantly defined spots distributed uniformly at sites of cell-cell junctions along the cell membrane. Cd caused gap-junction disassembly; Cx43 moved out of the membrane and into the cytoplasm around the nucleus. Chromatin changes in nuclei were assessed by DAPI staining. They revealed uniform nuclear staining in control and LA groups, but distorted nuclei and chromatin condensation in the Cd-treated group. These changes could be reversed by LA. Then, we investigated the mRNA expression of Cx43 using qRTPCR. Relative expression of Cx43 significantly $(p<0.01)$ decreased induced by Cd, and LA significantly $(p<0.01)$ attenuated it (Fig. 2D). In the Transwell culture system (Fig. 2E), while being co-cultured with Cd-exposed cells on the inside surface, the viability of BRL $3 \mathrm{~A}$ cells on the outside surface of inserts decreased and nuclei chromatin 

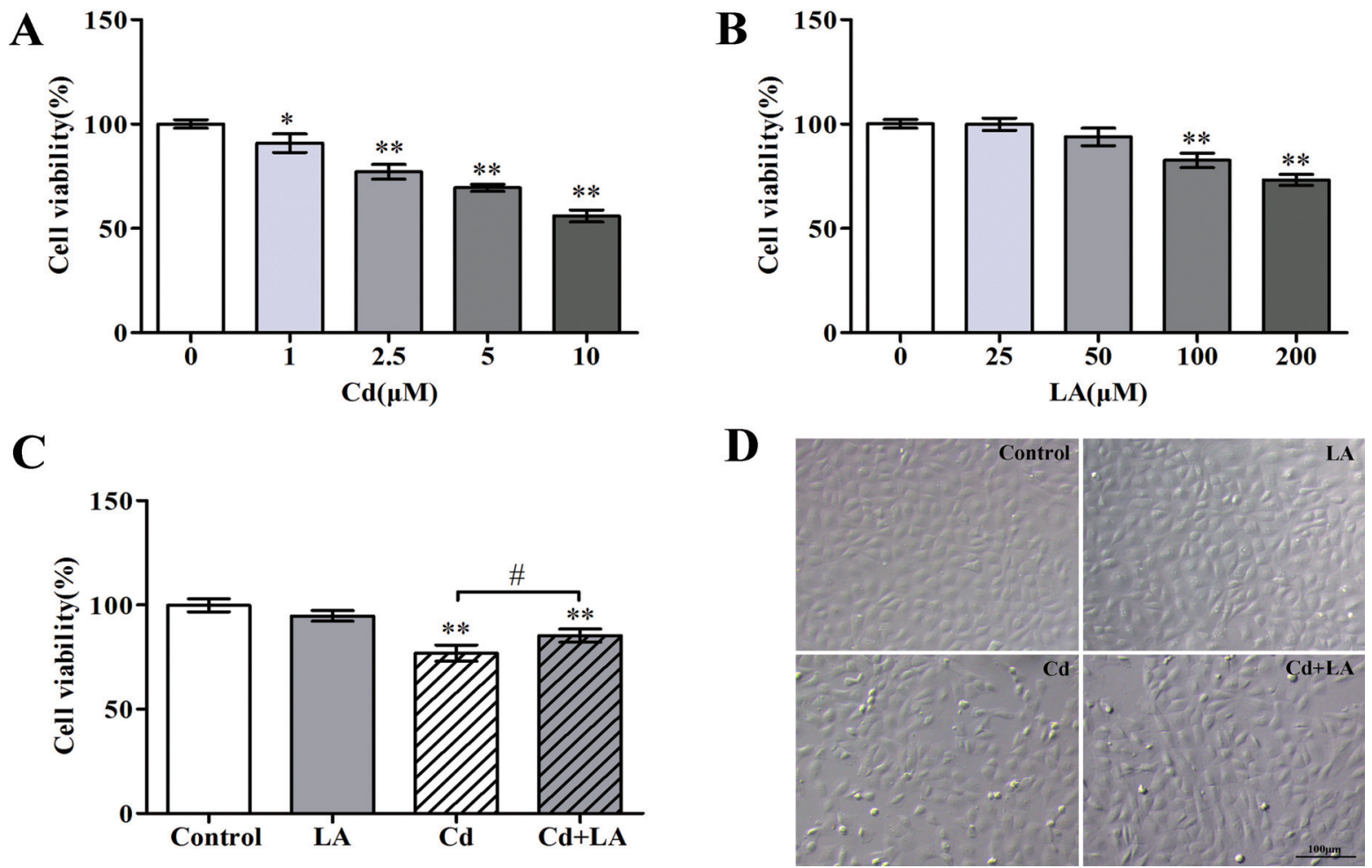

Fig. 1. Protective effects of LA on Cd-induced cytotoxicity in BRL 3A cells. A-C: Viability of BRL 3A cells treated with non-serum medium containing $\mathrm{Cd}(0-10 \mu \mathrm{M})$ and LA $(0-200 \mu \mathrm{M})$ for $12 \mathrm{hr}$, and co-treated with $\mathrm{LA}(50 \mu \mathrm{M})$ and $\mathrm{Cd}(2.5 \mu \mathrm{M})$ for $12 \mathrm{hr}$ was evaluated by the MTT assay. Results are the mean \pm S.D. $(\mathrm{n}=9) .{ }^{*} p<0.05,{ }^{* *} p<0.01$ compared with control group and $\# p<0.05$ as indicated. D: Morphologic alterations in BRL 3A cells treated with $50 \mu \mathrm{M}$ LA and $2.5 \mu \mathrm{M}$ Cd for $12 \mathrm{hr}$. Images were taken with a Leica inverted phase-contrast microscope (4006) equipped with a Quick Imaging system. Scale bar: $100 \mu \mathrm{m}$.

became condensed (and even nuclear fragmentation could be observed), these injuries could be ameliorated with LA or $50 \mu \mathrm{M} \mathrm{CBX}$ (prototypical blocker of gap junctions) added in the co-culture medium.

\section{Protective effects of LA on Cd-induced elevation of $\left[\mathrm{Ca}^{2+}\right]_{i}$ in BRL $3 A$ cells}

$\mathrm{Cd}$ induced significant increase in $\left[\mathrm{Ca}^{2+}\right]_{\mathrm{i}}(p<0.01)$, and LA could rescue the $\left[\mathrm{Ca}^{2+}\right]_{\mathrm{i}}$ elevation $(p<0.05)$ (Fig. 3A). $5 \mu \mathrm{M}$ BAPTA-AM (a chelator of intracellular $\mathrm{Ca}^{2+}$ ) or $100 \mu \mathrm{M}$ EGTA (a chelator of extracellula $\mathrm{Ca}^{2+}$ ) attenuated the reduction in cell viability induced by $\mathrm{Cd}$ (Fig. 3B and C). CaM is a multifunctional $\mathrm{Ca}^{2+}$-binding protein located in the cytoplasm and in various cellular organelles. We carried out qRT-PCR analyses to ascertain if $\mathrm{CaM}$ might be involved in $\mathrm{Cd}$-induced cytotoxicity in BRL 3A cells. Cd markedly down-regulated the $\mathrm{CaM}$ expression and LA prevented it $(p<0.01)$ (Fig. 3D). These results suggested that $\mathrm{Cd}$-induced cytotoxicity can be attributed to elevation of $\left[\mathrm{Ca}^{2+}\right]_{\mathrm{i}}$. CaM may play an important part in Cd-induced cytotoxicity, and the protective effect of LA is mediated by its ability to block $\left[\mathrm{Ca}^{2+}\right]_{\mathrm{i}}$ elevation.

\section{Interaction between GJIC and $\mathrm{Ca}^{2+}$ signaling plays an important part in Cd-induced cytotoxicity in BRL 3A cells}

To assess the interaction between GJIC and $\mathrm{Ca}^{2+}$ signaling after Cd-induced cytotoxicity, CBX and EGTA were administered in combination with $\mathrm{Cd}$. Co-treatment with $\mathrm{Cd}(2.5 \mu \mathrm{M})$ and $\mathrm{CBX}(50 \mu \mathrm{M})$, or co-treatment with $\mathrm{Cd}$ $(2.5 \mu \mathrm{M}), \mathrm{CBX}(50 \mu \mathrm{M})$ and EGTA $(100 \mu \mathrm{M})$, extremely significantly or significantly $(p<0.01, p<0.05)$ decreased cell viability and exacerbated $\left[\mathrm{Ca}^{2+}\right]_{\mathrm{i}}$ elevation compared with treatment with $2.5 \mu \mathrm{M} \mathrm{Cd}$ alone, respectively, whereas co-treatment with $\mathrm{Cd}(2.5 \mu \mathrm{M}), \mathrm{CBX}$ $(50 \mu \mathrm{M})$, and BAPTA-AM $(5 \mu \mathrm{M})$ significantly attenuated the $\left[\mathrm{Ca}^{2+}\right]_{\mathrm{i}}$ elevation induced by Cd in BRL 3A cells 
Alpha-Lipoic acid and Cd-induced increases in $\left[\mathrm{Ca}^{2+}\right]_{i}$
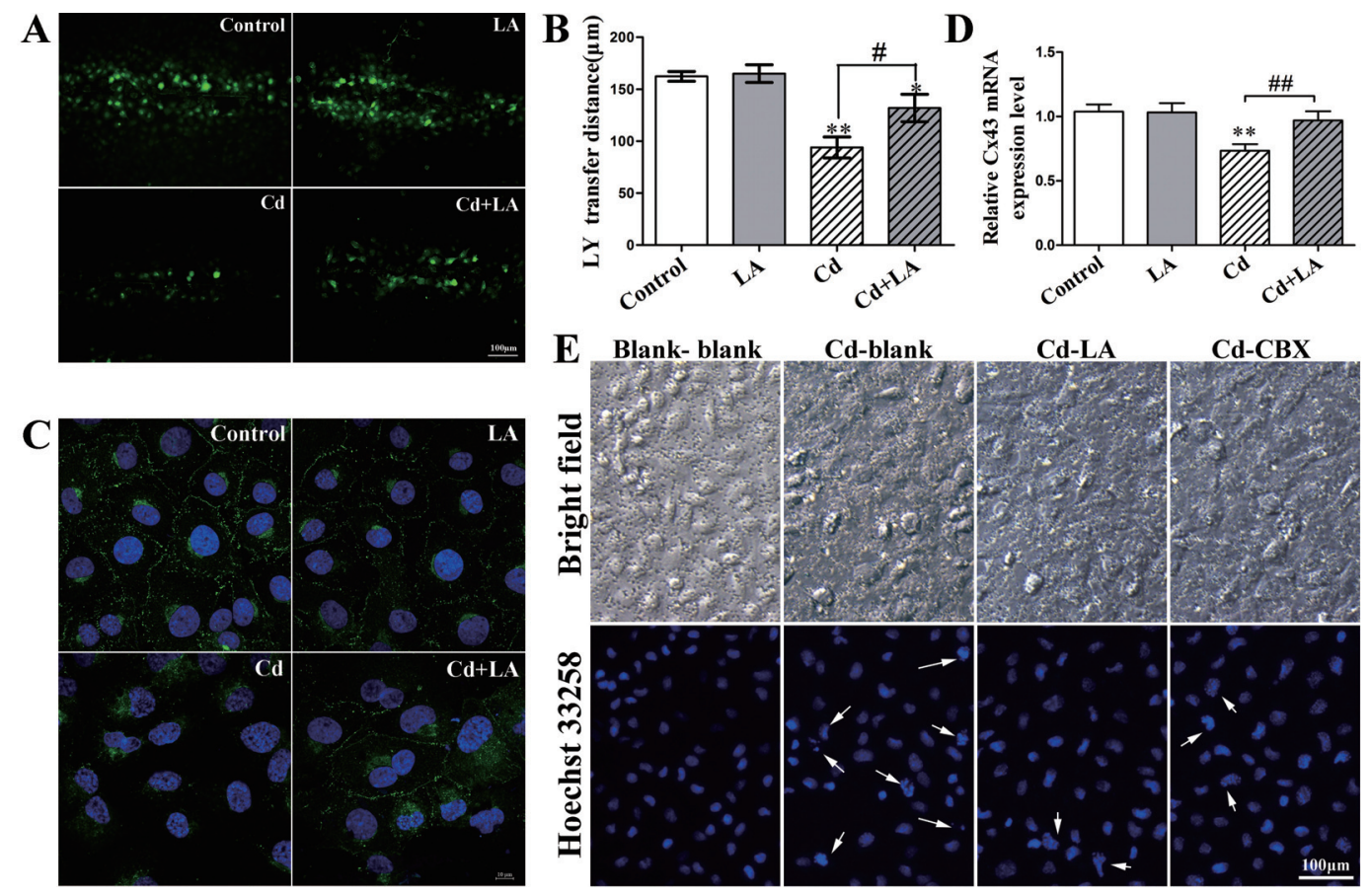

Fig. 2. Protective effects of LA on Cd-induced GJIC inhibition. A, B: Effect of LA on Cd (2.5 $\mu \mathrm{M})$-induced down-regulation of GJIC in BRL 3A cells. Scale bar $=100 \mu \mathrm{m}$. Mean distance of LY spread from the side of the scraped edge from six sites in each sample was obtained for quantification; C: Effect of LA on Cd (2.5 $\mu \mathrm{M})$-induced Cx43 distribution in BRL 3A cells. Cells were stained for $\mathrm{Cx} 43$ (green) and nuclei were counterstained with DAPI (blue). Scale bar $=10 \mu \mathrm{m}$. D: Effect of LA on $\mathrm{Cd}(2.5 \mu \mathrm{M})$-induced decreases in expression of Cx43 mRNA in BRL 3A cells. Values are the mean \pm S.D. $(n=9)$. ${ }^{* *} p<0.01$ compared with the control group, $\# p<0.05$, \#\#p<0.01 compared with the group indicated. E: BRL 3A cells influenced by $\mathrm{Cd}(10 \mu \mathrm{M})$-exposed cells in a Transwell culture system. Cells were divided between the two sides of the insert according to their treatment. Scale bar $=100 \mu \mathrm{m}$. Arrows indicate distorted nuclei and chromatin condensation.

(Fig. 4A and B). Subsequently, GJIC was measured: BAPTA-AM and EGTA blocked the GJIC inhibition induced by $\mathrm{Cd}$, whereas CBX intensified Cd-induced GJIC inhibition (Fig. 4C and D). These results suggested that $\mathrm{Cd}$ elevates $\left[\mathrm{Ca}^{2+}\right]_{\mathrm{i}}$ mainly from intracellular stores, and that blocking $\left[\mathrm{Ca}^{2+}\right]_{\mathrm{i}}$ elevation can ameliorate functional disorders of gap junctions.

\section{DISCUSSION}

The liver has been identified as the target of Cd-mediated toxicity (Dudley et al., 1984). At the cellular level, $\mathrm{Cd}$ has been associated with oxidative stress and apoptosis (Zhou et al., 2009). In the present study, we demonstrated that $\mathrm{Cd}$ induces cytotoxicity in BRL $3 \mathrm{~A}$ cells by inhibiting GJIC and triggering elevation of $\left[\mathrm{Ca}^{2+}\right]_{\mathrm{i}}$ by stimulating $\mathrm{Ca}^{2+}$ release from intracellular stores. In addition, we explored the possible protective effect of LA. Our results showed that LA may be a functional chemopreventative agent which could ameliorate the cytotoxic effects of $\mathrm{Cd}$ via $\mathrm{GJIC}$ and $\mathrm{Ca}^{2+}$ signaling.

GJIC is one of the most important mechanisms of cellular communications. The liver was one of the first organs in which GJIC was studied (Vinken et al., 2008). $\mathrm{Cd}$ is known to inhibit GJIC in the mouse liver in a timeand concentration-dependent manner, and this inhibition is correlated with a decrease in the expression of connexins (Jeong et al., 2000). In the present study, Cd induced inhibition of GJIC and down-regulation of expression of Cx43 mRNA in BRL 3A cells (Fig. 2A, B and D). Correspondingly, the cellular $\mathrm{Cx} 43$ decreased and scattered by Cd (Fig. 2C), LA partly alleviate these injury. Our results imply that LA is involved in the protective mechanisms against GJIC inhibition-induced liver injury. Studies have suggested that apoptotic cells can spatially extend apoptosis to healthy cells through communication of celldeath signals via GJIC (Decrock et al., 2009). Transwell inserts (pore size, $0.4 \mu \mathrm{m}$ ) were used in a co-culture system in the present study. Both sides of cells could not cross through the insert membrane but shared small-size 

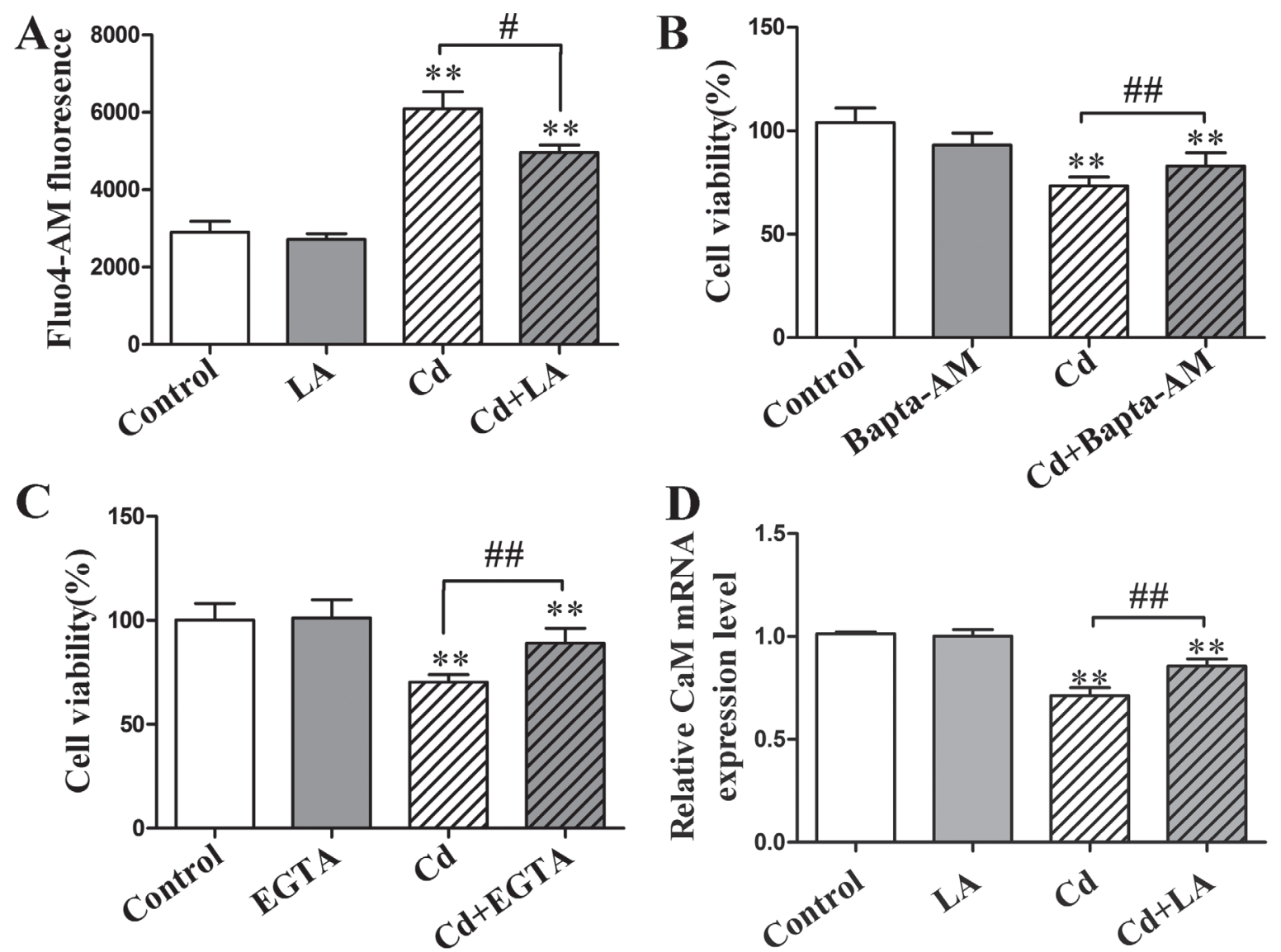

Fig. 3. Protective effects of LA on Cd-induced $\left[\mathrm{Ca}^{2+}\right]_{\mathrm{i}}$ elevation in BRL $3 \mathrm{~A}$ cells. A: Cd $(2.5 \mu \mathrm{M})$-induced elevation of $\left[\mathrm{Ca}^{2+}\right]_{\mathrm{i}}$ in BRL 3A cells was diminished by LA treatment (12 hr). Results are the mean fluorescence. Each bar represents mean \pm S.D. $(\mathrm{n}=4)$. B, C: BRL 3A cells were pretreated with BAPTA-AM $(5 \mu \mathrm{M})$ or EGTA $(100 \mu \mathrm{M})$ for 30 min, followed by treatment with $2.5 \mu \mathrm{M} \mathrm{Cd}$ for $12 \mathrm{hr}$. The cell viability was evaluated by the MTT assay. Results are the mean \pm S.D. (n = 9). D: Effect of LA on Cd $(2.5 \mu \mathrm{M})$-induced decreases in expression of CaM mRNA in BRL 3A cells. Values are the mean \pm S.D. $(n=9)$. $* * p<0.01$ compared with the control group, $\# p<0.05$, \#\#p $<0.01$ compared with the group indicated.

substances could do so via hemi-channels and/or establishment of gap junctions (cells cannot cross through the insert membrane if the pore size is $<3 \mu \mathrm{m})$. CBX is a GJIC blocker, and had a protective effect on the injury induced by Cd-exposed cells (Fig. 2E). Similar findings have been reported in PC12 cells (Guo et al., 2014). Our data allowed us to infer that GJIC inhibition has a protective effect that blocks communication of cell-death signals from injured cells to healthy cells.

$\mathrm{Ca}^{2+}$ is a universal messenger that regulates many aspects of the physiologic and pathologic functions of cells (Berridge et al., 2000). If cells are activated by extracellular stimuli, $\left[\mathrm{Ca}^{2+}\right]_{\mathrm{i}}$ can rise by more than fivefold via $\mathrm{Ca}^{2+}$ influx from outside of the cells and/or release from intracellular stores (Ishikawa et al., 2011).
Studies have demonstrated that $\left[\mathrm{Ca}^{2+}\right]_{\mathrm{i}}$ elevation is a common signal during Cd-induced apoptosis and death in several cell types (Yuan et al., 2013; Son et al., 2010; Xu et al., 2013). We demonstrated that $\mathrm{Cd}$ induces $\left[\mathrm{Ca}^{2+}\right]_{\mathrm{i}}$ elevation in BRL 3A cells (Fig. 3A). We used BAPTA-AM to chelate intracellular $\mathrm{Ca}^{2+}$ to demonstrate that $\left[\mathrm{Ca}^{2+}\right]_{i}$ elevation has a crucial role in Cd-induced cytotoxicity in BRL $3 \mathrm{~A}$ cells (Fig. 3B). We found that chelating extracellular $\mathrm{Ca}^{2+}$ with EGTA and co-treatment with LA also elicited protective effects (Fig. 3A and C). We hypothesized that EGTA disrupts $\mathrm{Ca}^{2+}$ homeostasis and impels $\mathrm{Ca}^{2+}$ removal from the cytoplasm, and LA is involved in the protective mechanisms against $\left[\mathrm{Ca}^{2+}\right]_{\mathrm{i}}$ elevation-induced liver injury. $\left[\mathrm{Ca}^{2+}\right]_{\mathrm{i}}$ elevation induces cellular injury by activating a signaling cascade that is mediated primarily via 
Alpha-Lipoic acid and Cd-induced increases in $\left[\mathrm{Ca}^{2+}\right]_{\mathrm{i}}$
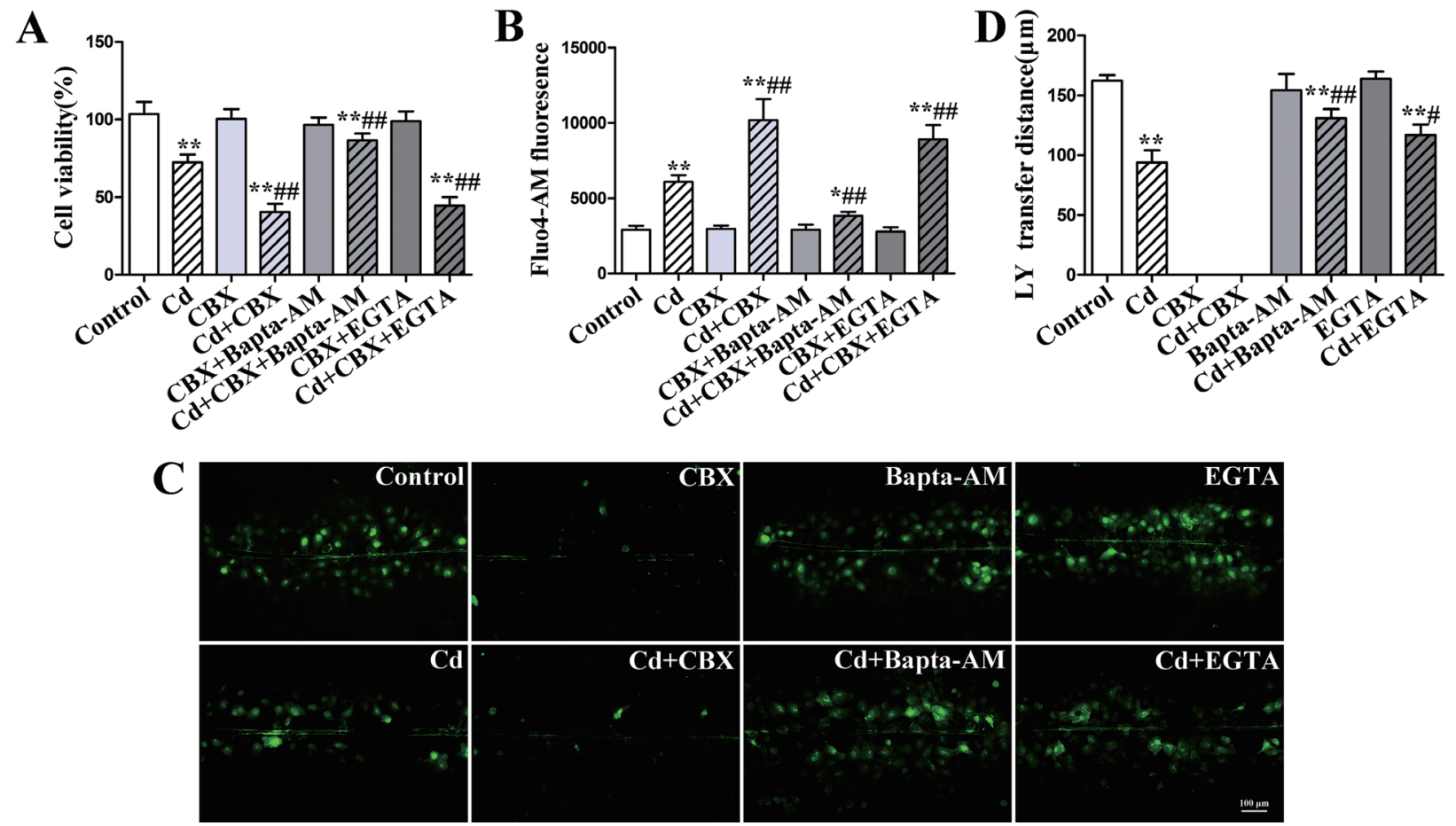

Fig. 4. Interaction between GJIC and $\mathrm{Ca}^{2+}$ signaling in Cd-induced cytotoxicity of BRL $3 \mathrm{~A}$ cells. A: The cell viability was evaluated by the MTT assay. Results are the mean \pm S.D. $(n=9)$. B: $\left[\mathrm{Ca}^{2+}\right]_{i}$ was measured after treatment as shown in A. Results are the mean fluorescence. Each bar represents mean \pm S.D. $(n=4)$. C, D: Effect of $50 \mu \mathrm{M}$ CBX, $5 \mu$ M BAPTA-AM, and $100 \mu \mathrm{M}$ EGTA on Cd $(2.5 \mu \mathrm{M})$-induced down-regulation of GJIC in BRL 3A cells. Scale bar $=100 \mu \mathrm{m} .{ }^{*} p<0.05$, $* * p<0.01$ compared with the control group, $\# p<0.05$, \#\#p<0.01 compared with the $2.5 \mu \mathrm{M}$ Cd group.

$\mathrm{Ca}^{2+}$-binding proteins such as CaM (Wang, 1985). CaM signaling might be involved in Cd-induced cytotoxicity (Fig. 3D).

$\mathrm{Ca}^{2+}$ is removed from cells by the $\mathrm{Na}^{+}-\mathrm{Ca}^{2+}$ exchanger and plasma-membrane $\mathrm{Ca}^{2+}$-ATPase. $\mathrm{Ca}^{2+}$ enters cells via voltage-gated calcium channels, receptor-operated channels, and store-operated channels. Endoplasmic reticula and mitochondria also take part in maintaining calcium homeostasis (Gurkoff et al., 2013; Berridge et al., 2003). It is accepted that $\mathrm{Ca}^{2+}$ can pass through gap-junction channels. The GJIC blocker CBX exacerbated the decrease in $\mathrm{Cd}$-induced cell viability in BRL $3 \mathrm{~A}$ cells (Fig. 4A), which was the opposite effect compared with that of CBX in the Transwell co-culture system, one of the reasons was that $\mathrm{CBX}$ further elevated the $\left[\mathrm{Ca}^{2+}\right]_{\mathrm{i}}$ induced by $\mathrm{Cd}$ (Fig. 4B). It seems that GJIC inhibition exacerbates injury in damaged cells. Combined activity of CBX and BAPTA-AM demonstrated that chelation of intracellular $\mathrm{Ca}^{2+}$ ameliorated $\mathrm{Cd}$-induced cell injury, whereas the combined activity of CBX and EGTA had an aggravating effect. We concluded that GJIC inhibition limits $\mathrm{Ca}^{2+}$ passage, in particular extruding $\left[\mathrm{Ca}^{2+}\right]_{\mathrm{i}}$ to the outside of cells, and that $\mathrm{Cd}$ elevates $\left[\mathrm{Ca}^{2+}\right]_{\mathrm{i}}$ mainly from intracellular stores. Similar findings have been reported in PC12 cells (Xu et al., 2011). Intercellular communication mediated by gap junctions can be regulated by multiple factors, including $\left[\mathrm{Ca}^{2+}\right]_{\mathrm{i}}, \mathrm{H}^{+}, \mathrm{CaM}$, voltage, and phosphorylation or expression of connexin subunits (Del Corsso et al., 2012; Vinken et al., 2006). [ $\left.\mathrm{Ca}^{2+}\right]_{\mathrm{i}}$ regulates gap-junction communication by uncoupling cells from each other by electric and metabolic means (Peracchia, 2004). Similar results were noted in our study: blockade of Cd-induced $\left[\mathrm{Ca}^{2+}\right]_{\mathrm{i}}$ elevation by BAPTA-AM, and co-treatment with $\mathrm{Cd}$ and EGTA recovers the functions of gap junctions (Fig. 4C and D), furthermore LA has a similar effect (Fig. 2A and B). In addition, the CaM binding sites of several intracellular domains of connexins blockade gapjunction channels (Zou et al., 2014b). Overall, the interaction between GJIC and calcium pathways has an important role in $\mathrm{Cd}$-induced cytotoxicity.

In summary, the results obtained in the present study clearly demonstrate that exposure to $\mathrm{Cd}$ causes GJIC 
inhibition and $\left[\mathrm{Ca}^{2+}\right]_{\mathrm{i}}$ elevation, followed by cell injury in BRL $3 \mathrm{~A}$ cells. Increases in $\left[\mathrm{Ca}^{2+}\right]_{\mathrm{i}}$ induced by $\mathrm{Cd}$ originate mainly from intracellular stores. Inhibition of GJIC restricts $\mathrm{Ca}^{2+}$ passage out of cells, which exacerbates the $\left[\mathrm{Ca}^{2+}\right]_{\mathrm{i}}$ elevation and cytotoxicity induced by $\mathrm{Cd}$. Previous studies provided evidence that LA attenuated Cd-induced cytotoxicity because of its antioxidation, in this study, LA elicits a partial protective effect on Cd-induced toxicity via $\mathrm{GJIC}$ and $\mathrm{Ca}^{2+}$ signaling. These results help to improve our understanding of $\mathrm{Cd}$-induce hepatotoxicity.

\section{ACKNOWLEDGMENTS}

This work was supported by the National Natural Science Foundation of China (No. 31372495, No. 31302058) and a project Funded by Priority Academic Program Development of Jiangsu Higher Education Institutions (PAPD)

Conflict of interest---- The authors declare that there is no conflict of interest.

\section{REFERENCES}

Al-Majed, A.A., Gado, A.M., Al-Shabanah, O.A. and Mansour, M.A. (2002): Alpha-lipoic acid ameliorates myocardial toxicity induced by doxorubicin. Pharmacol. Res., 46, 499-503.

Alexander, D.B. and Goldberg, G.S. (2003): Transfer of biologically important molecules between cells through gap junction channels. Curr. Med. Chem., 10, 2045-2058.

Berridge, M.J., Bootman, M.D. and Roderick, H.L. (2003): Calcium signalling: dynamics, homeostasis and remodelling. Nat. Rev. Mol. Cell. Biol., 4, 517-529.

Berridge, M.J., Lipp, P. and Bootman, M.D. (2000): The versatility and universality of calcium signalling. Nat. Rev. Mol. Cell. Biol., 1, 11-21.

Boucherie, S., Decaens, C., Verbavatz, J.M., Grosse, B., Erard, M., Merola, F., Cassio, D. and Combettes, L. (2013): Cadmium disorganises the scaffolding of gap and tight junction proteins in the hepatic cell line WIF B9. Biol. Cell., 105, 561-575.

Choong, G., Liu, Y. and Templeton, D.M. (2014): Interplay of calcium and cadmium in mediating cadmium toxicity. Chem. Biol. Interact., 211, 54-65.

Clapham, D.E. (2007): Calcium signaling. Cell., 131, 1047-1058.

Decrock, E., De Vuyst, E., Vinken, M., Van Moorhem, M., Vranckx, K., Wang, N., Van Laeken, L., De Bock, M., D’Herde, K., Lai, C.P., Rogiers, V., Evans, W.H., Naus, C.C. and Leybaert, L. (2009): Connexin 43 hemichannels contribute to the propagation of apoptotic cell death in a rat C6 glioma cell model. Cell. Death. Differ., 16, 151-163.

Del Corsso, C., Iglesias, R., Zoidl, G., Dermietzel, R. and Spray, D.C. (2012): Calmodulin dependent protein kinase increases conductance at gap junctions formed by the neuronal gap junction protein connexin36. Brain Res., 1487, 69-77.

Dudley, R.E., Svoboda, D.J. and Klaassen, C.D. (1984): Time course of cadmium-induced ultrastructural changes in rat liver. Toxicol. Appl. Pharmacol., 76, 150-160.
El-Fouly, M.H., Trosko, J.E. and Chang, C.-C. (1987): Scrape-loading and dye transfer. A rapid and simple technique to study gap junctional intercellular communication. Exp. Cell. Res., 168, $422-430$.

Guo, S., Zhou, J., Chen, X., Yu, Y., Ren, M., Hu, G., Liu, Y. and Zou, F. (2014): Bystander effects of PC12 cells treated with $\mathrm{Pb}^{2+}$ depend on ros-mitochondria-dependent apoptotic signaling via gap-junctional intercellular communication. Toxicol. Lett., 229 , 150-157.

Gurkoff, G., Shahlaie, K., Lyeth, B. and Berman, R. (2013): Voltage-gated calcium channel antagonists and traumatic brain injury. Pharmaceuticals, 6, 788-812.

Han, F., Yan, S. and Shi, Y. (2013): Single-prolonged stress induces endoplasmic reticulum-dependent apoptosis in the hippocampus in a rat model of post-traumatic stress disorder. PLoS. One, 8, e69340.

Hu, W., Jones, P.D., Upham, B.L., Trosko, J.E., Lau, C. and Giesy, J.P. (2002): Inhibition of gap junctional intercellular communication by perfluorinated compounds in rat liver and dolphin kidney epithelial cell lines in vitro and Sprague-Dawley rats in vivo. Toxicol. Sci., 68, 429-436.

Hussein, S.A., Omnia, M. and Fayed, A.M.S. (2014): Protective effects of alpha-lipoic acid and melatonin against cadmium-induced oxidative stress in erythrocytes of rats. J. Pharmacol. Toxicol., 9, DOI: 10.3923/jpt.2014.1.24

Ishikawa, M., Iwamoto, T., Nakamura, T., Doyle, A., Fukumoto, S. and Yamada, Y. (2011): Pannexin 3 functions as an ER Ca(2+) channel, hemichannel, and gap junction to promote osteoblast differentiation. J. Cell. Biol., 193, 1257-1274.

Järup, L. and Åkesson, A. (2009): Current status of cadmium as an environmental health problem. Toxicol. Appl. Pharmacol., 238, 201-208.

Jeong, S.-H., Habeebu, S.S. and Klaassen, C.D. (2000): Cadmium decreases gap junctional intercellular communication in mouse liver. Toxicol. Sci., 57, 156-166.

Liu, N., Huang, H., Liu, S., Li, X., Yang, C., Dou, Q.P. and Liu, J. (2014): Calcium channel blocker verapamil accelerates gambogic acid-induced cytotoxicity via enhancing proteasome inhibition and ROS generation. Toxicol. In Vitro, 28, 419-425.

Peracchia, C. (2004): Chemical gating of gap junction channels; roles of calcium, $\mathrm{pH}$ and calmodulin. Biochim. Biophys. Acta., 1662, 61-80.

Rennolds, J., Malireddy, S., Hassan, F., Tridandapani, S., Parinandi, N., Boyaka, P.N. and Cormet-Boyaka, E. (2012): Curcumin regulates airway epithelial cell cytokine responses to the pollutant cadmium. Biochem. Biophys. Res. Commun., 417, 256-261.

Son, Y.O., Lee, J.C., Hitron, J.A., Pan, J., Zhang, Z. and Shi, X. (2010): Cadmium induces intracellular Ca2+- and H2O2-dependent apoptosis through JNK- and p53-mediated pathways in skin epidermal cell line. Toxicol. Sci., 113, 127-137.

Thévenod, F. (2009): Cadmium and cellular signaling cascades: to be or not to be? Toxicol. Appl. Pharmacol., 238, 221-239.

Veljkovic, A.R., Nikolic, R.S., Kocic, G.M., Pavlovic, D.D., Cvetkovic, T.P., Sokolovic, D.T., Jevtovic, T.M., Basic, J.T., Laketic, D.M., Marinkovic, M.R., Stojanovic, S.R., Djordjevic, B.S. and Krsmanovic, M.M. (2012): Protective effects of glutathione and lipoic acid against cadmium-induced oxidative stress in rat's kidney. Ren. Fail., 34, 1281-1287.

Vinken, M., Decrock, E., De Vuyst, E., Ponsaerts, R., D'hondt, C., Bultynck, G., Ceelen, L., Vanhaecke, T., Leybaert, L. and Rogiers, V. (2011): Connexins: sensors and regulators of cell 
Alpha-Lipoic acid and Cd-induced increases in $\left[\mathrm{Ca}^{2+}\right]_{\mathrm{i}}$

cycling. Biochim. Biophys. Acta., 1815, 13-25.

Vinken, M., Henkens, T., De Rop, E., Fraczek, J., Vanhaecke, T. and Rogiers, V. (2008): Biology and pathobiology of gap junctional channels in hepatocytes. Hepatology., 47, 1077-1088.

Vinken, M., Vanhaecke, T., Papeleu, P., Snykers, S., Henkens, T. and Rogiers, V. (2006): Connexins and their channels in cell growth and cell death. Cell. Signal., 18, 592-600.

Wang, C.L. (1985): A note on Ca2+ binding to calmodulin. Biochem. Biophys. Res. Commun., 130, 426-430.

Wu, X., Ahn, E.Y., McKenna, M.A., Yeo, H. and McDonald, J.M. (2005): Fas binding to calmodulin regulates apoptosis in osteoclasts. J. Biol. Chem., 280, 29964-29970.

Xu, B., Chen, S., Luo, Y., Chen, Z., Liu, L., Zhou, H., Chen, W., Shen, T., Han, X., Chen, L. and Huang, S. (2011): Calcium signaling is involved in cadmium-induced neuronal apoptosis via induction of reactive oxygen species and activation of MAPK/ mTOR network. PLoS. One, 6, e19052.

Xu, S., Pi, H., Chen, Y., Zhang, N., Guo, P., Lu, Y., He, M., Xie, J., Zhong, M., Zhang, Y., Yu, Z. and Zhou, Z. (2013): Cadmium induced Drp1-dependent mitochondrial fragmentation by disturbing calcium homeostasis in its hepatotoxicity. Cell. Death. Dis., 4, e540.
Yu, W., Niwa, T., Miura, Y., Horio, F., Teradaira, S., Ribar, T.J., Means, A.R., Hasegawa, Y., Senda, T. and Niki, I. (2002): Calmodulin overexpression causes $\mathrm{Ca}^{2+}$-dependent apoptosis of pancreatic beta cells, which can be prevented by inhibition of nitric oxide synthase. Lab. Invest., 82, 1229-1239.

Yuan, Y., Jiang, C.Y., Xu, H., Sun, Y., Hu, F.F., Bian, J.C., Liu, X.Z., Gu, J.H. and Liu, Z.P. (2013): Cadmium-induced apoptosis in primary rat cerebral cortical neurons culture is mediated by a calcium signaling pathway. PLoS. One, 8, e64330.

Zhou, Y.J., Zhang, S.P., Liu, C.W. and Cai, Y.Q. (2009): The protection of selenium on ROS mediated-apoptosis by mitochondria dysfunction in cadmium-induced LLC-PK(1) cells. Toxicol. In Vitro, 23, 288-294.

Zou, H., Hu, D., Han, T., Zhao, H., Xie, J., Liu, X., Wang, Y., Gu, J., Yuan, Y., Bian, J. and Liu, Z. (2014a): Salidroside Ameliorates Cd-Induced Calcium Overload and Gap Junction Dysfunction in BRL 3A Rat Liver Cells. Biol. Trace. Eelem Res., DOI: 10.1007/s12011-014-0201-7.

Zou, J., Salarian, M., Chen, Y., Veenstra, R., Louis, C.F. and Yang, J.J. (2014b): Gap junction regulation by calmodulin. FEBS Lett., 588, 1430-1438. 